\title{
Exposure of natural Antarctic marine microbial assemblages to ambient UV radiation: effects on the marine microbial community
}

\author{
A. Davidson*, L. Belbin \\ Australian Antarctic Division, Channel Highway, Kingston, Tasmania 7050, Australia
}

\begin{abstract}
The effect of ambient solar UV radiation on natural protist (phytoplankton and protozoan) assemblages from Antarctic coastal waters was determined. Subsamples of the community were exposed to UV radiation attenuated to equivalent water column depths (ED) of 1.0, 2.0, 3.0, 3.6 and $\geq 20 \mathrm{~m}$ for periods of between $8 \mathrm{~h}$ and $1 \mathrm{wk}$. Total concentrations of phytoplankton in treatments exposed at 3.0 and $3.6 \mathrm{~m}$ ED were similar to those in control treatments. However, exposure of phytoplankton at $\leq 2.0 \mathrm{~m}$ ED for $\geq 1 \mathrm{~d}$ reduced overall cell size, concentration and biomass. Following UV exposure, some species of phytoplankton died, some flourished and others were unaffected. In contrast, the total concentrations of protozoans at $\leq 2.0 \mathrm{~m}$ ED for $\geq 1 \mathrm{~d}$ were commonly higher than in controls, and 2- to 3-fold higher than at 3.0 and $3.6 \mathrm{~m} \mathrm{ED}$. Significant negative correlation was observed between the total concentrations of phytoplankton and protozoa, showing that UV-induced mortality of phytoplankton resulted, directly or indirectly, in an increase in the concentrations of protozoans. Our results showed that UV radiation can change the biomass and species composition of marine microbial communities, altering size and availability of food for higher trophic levels and changing their trophic structure. Thus, increased UVB as a result of ozone depletion is likely to change food web structure and function and may influence biogeochemical cycles.
\end{abstract}

KEY WORDS: Antarctica · UVB radiation · Marine ecology · Phytoplankton · Protozoa $\cdot$ Bacteria Resale or republication not permitted without written consent of the publisher

\section{INTRODUCTION}

Stratospheric ozone concentrations over Antarctica during spring commonly fall below $50 \%$ and may decline below $30 \%$ of pre-ozone-hole values (Kerr 1998). Depletion of ozone persists until February, leading to a 50 to $100 \%$ increase in UVB (280 to $320 \mathrm{~nm}$ ) around the summer solstice (Frederick \& Lubin 1994, Jones \& Shanklin 1995). Thus, UVB radiation is enhanced throughout the period of greatest biological production in Antarctic waters. Ozone depletion currently enhances Antarctic erythemal UV around $130 \%$, and this enhancement is predicted to exceed $100 \%$ between the years 2010 and 2020, and continue to exceed $50 \%$ from 2040 to 2050 (Taalas et al. 2000).

*E-mail: andrew.davidson@aad.gov.au
Concern regarding the effect of UVB on the Antarctic biota has led to extensive literature on the photobiology of Antarctic organisms, most of which has focused on the impact of UVB on phytoplankton (e.g. reviews by Karentz 1994, Davidson 1998, Vernet 2000). The evidence that UVB radiation can damage plankton is overwhelming, reducing production, growth and survival (Karentz 1989, Karentz et al. 1991). Furthermore, large interspecific differences have been reported in the tolerance of phytoplankton to UVB exposure, which can result in UV-induced changes in species composition of mixed algal cultures and natural phytoplankton assemblages (Smith et al. 1992, Davidson et al. 1996, Vernet 2000 and references therein). The sea ice and marginal ice zone support much of the primary production in the Southern Ocean, and blooms coincide with ozone depletion during spring and early summer (Smith \& Nelson 1986, 
Voytek 1989). These environments are penetrated by biologically significant doses of UVB radiation (Smith et al. 1992, Ryan \& Beaglehole 1994). Thus, enhanced UVB irradiances coincide with the seasonal bloom of plankton in environments that are susceptible to UVB radiation.

Studies of the effect of UVB radiation on Antarctic marine microbial communities have been performed using a single species or communities of phytoplankton. However, phytoplankton production supports planktonic microbial communities of viruses, bacteria and protozoa, through which most of the organic matter in pelagic ecosystems are channelled (Azam 1998). Like phytoplankton, these organisms can be damaged or killed by solar UVB radiation but can also exhibit large species-specific differences in their sensitivity to UV exposure (for reviews see Jeffrey et al. 2000, Mostajir et al. 2000, Vernet 2000). UV-induced changes in their production, growth, survival and species composition are likely to cause changes in the trophodynamics of microbial communities. Bothwell et al. (1994) showed that studies using a single trophic level could not predict the effect of UVB on an ecosystem due to UVB-induced changes in trophic-level interactions. Yet to date, few studies have examined the effect of UV on natural marine assemblages, their findings vary greatly, and none have been performed in Antarctic waters (Keller et al. 1997a,b, Wickham \& Carstens 1998, Mostajir et al. 1999).

In this study we show that ambient Antarctic UV radiation can change the species composition and trophic structure of natural microbial communities from near-shore waters off Davis Station, Antarctica.

\section{MATERIALS AND METHODS}

The study was conducted at Davis Station between 8 and 18 January 1998. The influence of UV radiation on the natural protist community was determined using aliquots of the same samples used to determine the previously published effect of UV on the bacterioplankton. For detailed methods of sample acquisition, preparation and incubation see Davidson \& van der Heijden (2000).

Light measurement. Light measurements were made using an SR9910 Macam double grating spectroradiometer. Wavelengths between 280 and $400 \mathrm{~nm}$ were scanned at $1 \mathrm{~nm}$ wave-steps every 5 min during the in vivo exposure of protist assemblages to Antarctic solar radiation. The downwelling irradiance at each wavelength was multiplied by the percentage transmittance of WhirlPak (Nasco) bags and screens. The spectral irradiance of each light treatment was then erythemally weighted and compared with coincident measurements of erythemal UV collected using a 501B Solar Light UV-Biometer by the Australian Radiation Protection and Nuclear Safety Agency. Erythema was used due to its similarity to plant and DNA action spectra, ease of cross-calibration with Biometer data and the fact that the experiments examined interactive responses of an entire plankton community for which more specific physiological weighting functions were not applicable. Equivalent water column depths (ED) received by the plankton assemblages in each light treatment were calculated using Beer's Law (Kirk 1983) and the attenuation of surface irradiation by each screen.

Plankton sampling and exposure. Approximately 1001 of natural plankton assemblage was obtained from $2 \mathrm{~km}$ offshore, at $10 \mathrm{~m}$ depth beneath $1.7 \mathrm{~m}$ of snow-covered sea ice, on 7 January 1998. The seawater was filtered through a $200 \mu \mathrm{m}$ mesh into a sterile, acid-cleaned, polythene-lined 200 l stainless steel drum. Three replicate 11 subsamples of the microbial assemblage were obtained to determine the concentration of each protist taxon at the beginning of the experiment $\left(T_{0}\right)$. A further 132 replicate subsamples of around $350 \mathrm{ml}$ were transferred to $500 \mathrm{ml}$, sterile, UVtransmissive WhirlPak bags.

WhirlPak bags were exposed to ambient solar UV radiation in out-door incubation tanks. Thirty bags were placed beneath different thicknesses of borosilicate glass that attenuated UV to ED of 1.0, 2.0, 3.0 and $3.6 \mathrm{~m}$ (Fig. 1). Samples were exposed to UV for periods of $8 \mathrm{~h}$ and 1, 2, 4 and $7 \mathrm{~d}$, at the end of which 6 replicate WhirlPak bags from each light treatment were transferred beneath UV stabilised polycarbonate screening, which removed wavelengths $<375 \mathrm{~nm}$ ( $\geq 20 \mathrm{~m} \mathrm{ED}$ ), and the samples were allowed to grow (post-UV incubation). The total duration of UV exposure plus post-UV incubation for all bags was $10 \mathrm{~d}$. A further 12 bags were held beneath UV-stabilised polycarbonate $(\geq 20 \mathrm{~m})$ for $10 \mathrm{~d}$ ( $T_{10}$ controls). At the end of the $10 \mathrm{~d}$ period, incubated samples were prepared for analysis of the microbial community.

Plankton sample analyses. Following post-UV incubation, the 6 replicate WhirlPaks for each light treatment and exposure time were randomly paired and the pairs pooled. A known volume (approximately half) of the sample was transferred to a glass 11 bottle and fixed with $1 \mathrm{ml}$ of acid Lugol's iodine. Fixation with Lugol's iodine can result in significant loss of ciliate and flagellate cells ( Klein Breteler 1985, Ohman \& Snyder 1991); however, other fixatives such as formalin, formaldehyde and glutaraldehyde can also cause cell loss (Sherr \& Sherr 1993). Samples were allowed to sediment for $\geq 48 \mathrm{~h}$, the supernatant was removed by aspiration, and the concentrated samples ( 20 ml) were stored at $4^{\circ} \mathrm{C}$ prior to analysis. 


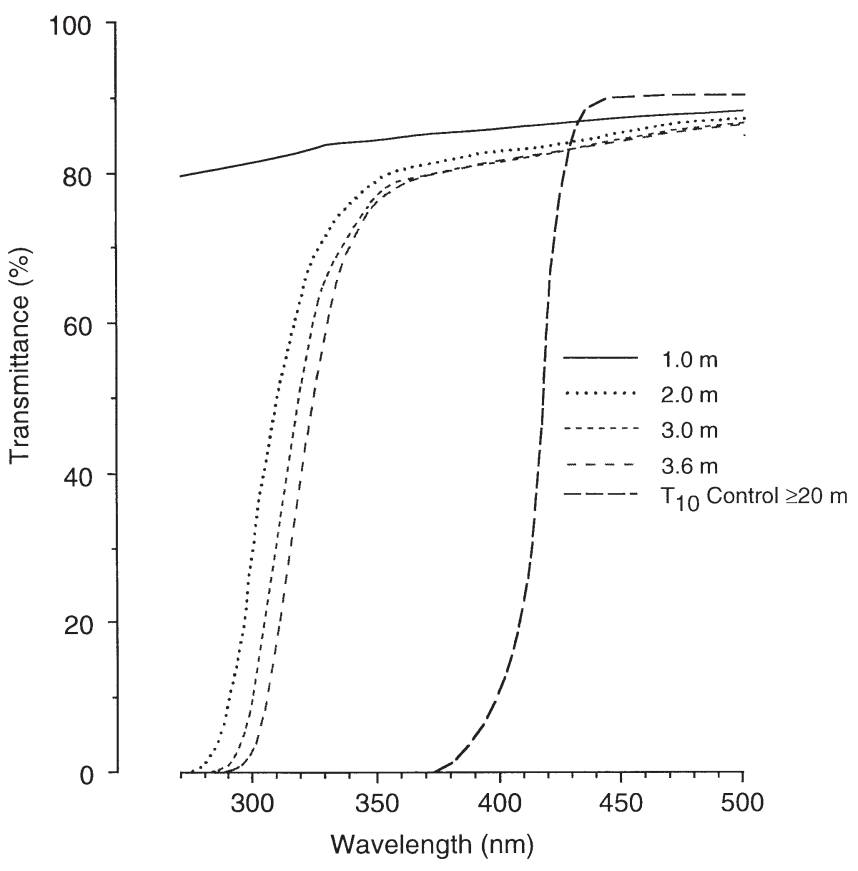

Fig. 1. Percentage transmittance of UV-attenuating screens between 270 and $500 \mathrm{~nm}$ wavelength and their equivalent depth in the water column. $T_{10}$ control $\geq 20 \mathrm{~m}$ is the polycarbonate-screened treatment that received no UV $<375 \mathrm{~nm}$. Equivalent water column depths of 1.0, 2.0, 3.0 and $3.6 \mathrm{~m}$ were obtained using polythene and 3.3, 5.5 and $9.0 \mathrm{~mm}$ thick borosilicate glass, respectively

Concentrated samples were sedimented in Utermöhl cylinders and observed using Nomarski optics on a Zeiss Axiovert inverted microscope equipped with blue light epifluorescence at 400 or $1000 \times$ magnification. Cells were counted over 5 randomly chosen microscope fields for each of the 3 independent replicate samples at each exposure time and light treatment. Protozoa were identified by the absence of chlorophyll autofluorescence under blue light excitation, and by the absence of chloroplasts and starch under transmitted light. To aid identification of protist species, samples of concentrate were also pipetted onto formvar-coated copper grids, fixed for $60 \mathrm{~s}$ with $2 \% \mathrm{OsO}_{4}$ vapour, rinsed gently with distilled water, air dried and shadow cast with chromium metal. Shadow-cast preparations were then examined using a Phillips CM 100 transmission electron microscope.

The mean and standard error of cell concentrations were then calculated for each phytoplankton and protozoan taxon. Concentrations of protists were compared with concentrations at $T_{0}$ to quantify growth or mortality of each taxon during exposure to experimental irradiances and $T_{10}$ control treatments to quantify changes in concentration due to UV irradiance and exposure duration.
Between 50 and 100 cells of each protist species were measured using an ocular micrometer at 400 or $1000 \times$ magnification, and cell volumes were calculated. The cell volumes of each species were multiplied by 1.33 to compensate for cell shrinkage as a result of Lugol's fixation (Dehairs et al. 1992). Cell carbon concentrations were calculated using the cell volume of each protist taxon and the following conversion stat-

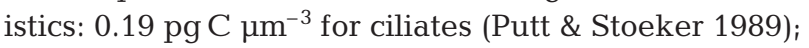
$0.183 \mathrm{pgC} \mathrm{mm}^{-3}$ for heterotrophic dinoflagellates

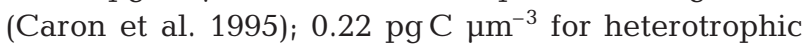
nanoflagellates (HNAN) (Børsheim \& Bratak 1987); and $\operatorname{pg} \mathrm{C}=0.109 \times(\text { live cell volume })^{0.991}$ for all other autotrophic and heterotrophic cells (Montagnes et al. 1994). The means and standard errors of the cell volumes of all phytoplankton and protozoa in each light treatment were also calculated and converted to equivalent spherical diameter (ESD).

Statistical analyses. Exploratory analysis: A statistical program named PATN (Belbin 1993) was used to examine the relationships between protist communities in each of the 375 replicate field counts independent of light treatment. The concentrations of protist taxa ranged over 4 orders of magnitude so the counts were relativised prior to analysis using the formula $Y_{i j}=$ $100 X_{i j} / \sum_{j=1}^{\mathrm{n}} X_{i j}$ (Field et al. 1982), where $Y_{i j}$ is transformed score, $X_{i j}$ is concentration of the $i$ th species in the $j$ th sample, and $\sum_{j=1}^{\mathrm{n}} X_{i j}$ is the sum of $X_{i j}$ over all samples. Transformation ensured, a priori, that each taxonomic group could make an equal contribution.

The taxonomic composition of incubated samples (UV-exposed and $T_{10}$ controls) was examined by cluster analysis. The Bray \& Curtis (1957) measure of association was used to generate a quantitative estimate of the taxonomic resemblance between each pair of the 375 microscope-field counts of protist taxa. These values were then subjected to flexible hierarchical clustering by unweighted pair-group using arithmetic average (UPGMA) (Belbin et al. 1992). After examination of the dendrogram structure, 7 descriptive groups were identified at an arbitrary dissimilarity of 0.54 . The difference in species compositions and probabilities of UV-induced changes in concentration between the 7 cluster groups were examined using box and whisker plots and F-statistics. The light treatments to which microscope-field counts were exposed in each cluster group were also examined. The frequency of each treatment (ED and durations of exposure) was then determined for each of the 7 cluster groups.

Confirmatory analyses: Multivariate analysis of variance (MANOVA) was performed to determine the statistical significance of UV-induced changes in protist assemblage using 12 protist taxa and relativised cell concentration (see above). 


\section{RESULTS}

\section{Erythemal UV}

The erythemal downwelling solar irradiance varied greatly during the experiment. Diurnal changes accounted for most of the variation, but cloud contributed significantly to attenuation of erythemal irradiance during Days 3, 4, 6 and 7 of the experiment. Days 1,2 and 5 remained largely cloud free. The increase in cumulative erythemal dose was approximately linear with increasing exposure time (Table 1). Ozone measurements at the nearby Chinese Antarctic station of Zhongshan showed that total column ozone ranged from around 140 DU in September and October to 380 DU during November during the 1997-98 summer, but column ozone during the experiment was around 300 DU. Thus, there was little enhancement of UVB radiation during the experiment due to ozone depletion overhead (Xiangdong et al. 1999).

\section{Total protists}

This section examines UV-induced changes in the total concentration and biomass of phytoplankton and protozoa. Changes in the concentration of individual phytoplankton and protozoan taxa are then considered. Other than at $T_{0}$, concentrations of cells and cell carbon were obtained from samples that were exposed to UV and post-UV incubated (exposure + post-UV incubation $=10 \mathrm{~d}$ ).

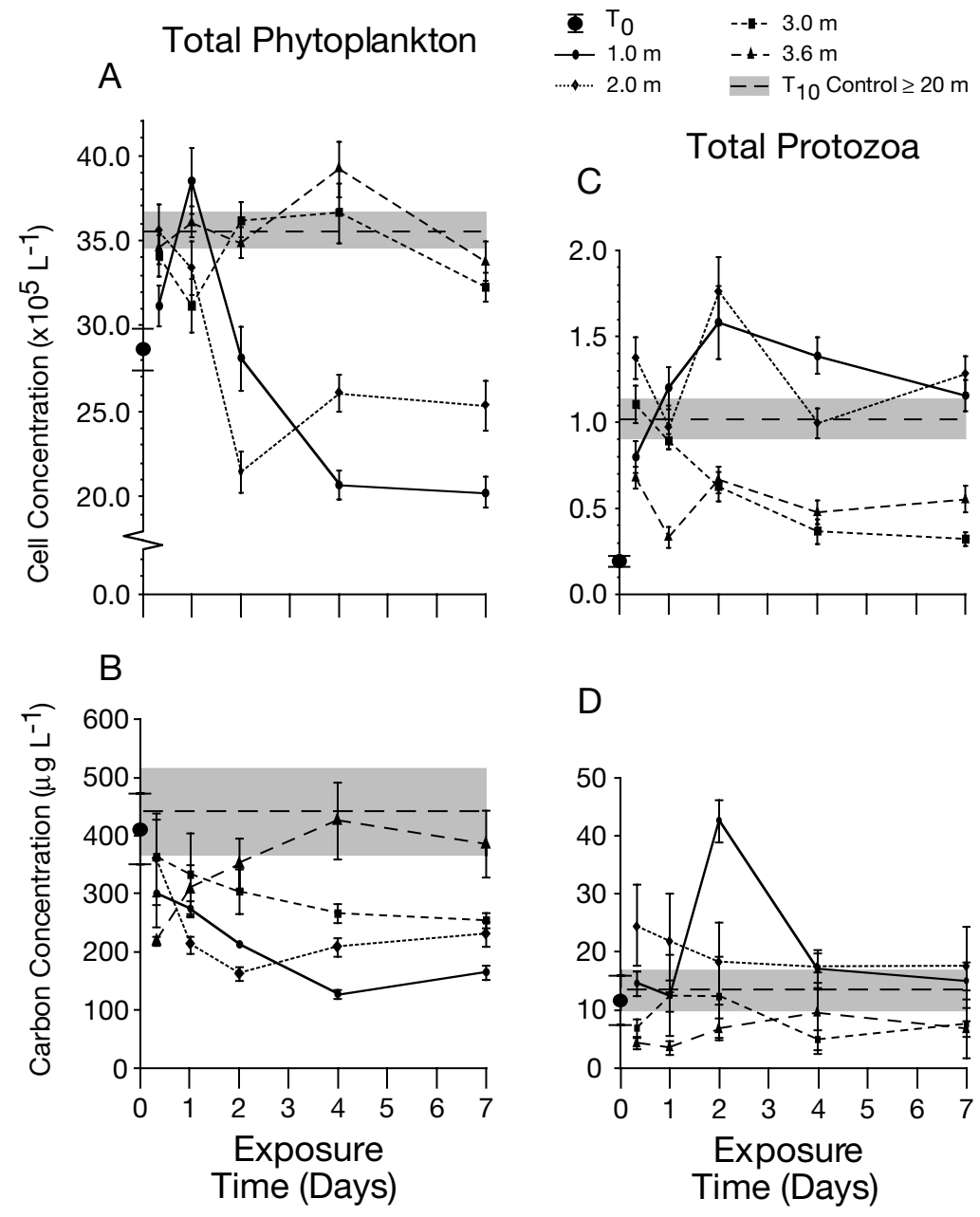

Fig. 2. Total concentrations of (A) phytoplankton cells and their calculated cell carbon (B), and (C) protozoan cells and their calculated cell carbon (D) following exposure to ambient solar irradiances at equivalent water column depths of 1.0, 2.0, 3.0 and $T_{10}$ control $\geq 20 \mathrm{~m}$ treatments for durations between $8 \mathrm{~h}$ and $7 \mathrm{~d}$ and post-UV incubation (irradiance + post-UV incubation $=10 \mathrm{~d}$ ). $T_{0}$ is the concentration at the beginning of the experiment. Error bars represent \pm 1 standard error. The shadowed area represents \pm 1 standard error for $T_{10}$ controls

\section{Phytoplankton}

Table 1. Cumulative erythemal UV dose $\left(\mathrm{kW} \mathrm{m}^{-2}\right)$ at the surface and 1.0,2.0,3.0, 3.6 and $\geq 20 \mathrm{~m}$ equivalent water column depths for each attenuated UV treatment for at each sample time

\begin{tabular}{|lcccccc|}
\hline \multirow{2}{*}{ Time } & \multicolumn{7}{c|}{ Depth (m) } \\
& Surface & 1.0 & 2.0 & 3.0 & 3.6 & $\geq 20$ \\
\hline $8 \mathrm{~h}$ & 3.46 & 2.18 & 1.47 & 1.04 & 0.77 & 0.00 \\
$1 \mathrm{~d}$ & 5.56 & 3.52 & 2.40 & 1.72 & 1.29 & 0.00 \\
$2 \mathrm{~d}$ & 8.82 & 5.57 & 3.83 & 2.75 & 2.09 & 0.00 \\
$4 \mathrm{~d}$ & 13.0 & 8.66 & 6.05 & 4.42 & 3.40 & 0.00 \\
$7 \mathrm{~d}$ & 22.2 & 14.1 & 9.96 & 7.33 & 5.67 & 0.00 \\
\hline
\end{tabular}

The total concentration of phytoplankton after $T_{10}$ control incubations was around $25 \%$ higher than that at $T_{0}$, indicating that phytoplankton grew in control treatments. Total phytoplankton concentrations exposed at 3.0 and $3.6 \mathrm{~m}$ ED remained similar to those in control treatments irrespective of the duration of exposure to UV and post-UV incubation (Fig. 2A). In contrast, phytoplankton concentrations following exposure to UV at $\leq 2.0 \mathrm{~m}$ ED for $\geq 2 \mathrm{~d}$ and post-UV incubation were around $40 \%$ lower than $T_{10}$ controls and $15 \%$ lower than at $T_{0}$ (Fig. 2A). Concentrations of phytoplankton in treatments exposed to UV for $\leq 1 \mathrm{~d}$ 
seldom differed significantly from $T_{10}$ controls, indicating that brief exposure to UV did not inhibit overall growth of phytoplankton during irradiance and postUV incubation.

Phytoplankton biomass in $T_{10}$ control treatments did not differ significantly from that at $T_{0}$ (Fig. 2B). Therefore, while the concentration of phytoplankton increased in $T_{10}$ controls (see above), the biomass did not. Carbon concentrations in treatments exposed for $\geq 2 \mathrm{~d}$ at $3.6 \mathrm{~m}$ ED and post-UV incubated were similar to concentrations at $T_{0}$ and in $T_{10}$ controls. However, in comparison with the $T_{10}$ controls, phytoplankton biomass at $3.0 \mathrm{~m}$ ED declined around $30 \%$ and 50 to $70 \%$ at $\leq 2.0 \mathrm{ED}$ (Fig. 2B). The rate of decline in biomass generally increased with increasing UV irradiance.

\section{Protozoa}

Concentrations of protozoa were approximately 5fold higher in $T_{10}$ control treatments than at $T_{0}$, showing substantial growth of microheterotrophs in the absence of short wavelength solar UV radiation (Fig. 2C). Protozoa also grew in all UV-exposed treatments as their concentrations were significantly higher than at $T_{0}$. Their concentrations were generally highest in treatments that were exposed at $\leq 2.0 \mathrm{~m}$ ED. Concentrations of protozoa peaked at around $1.65 \times 10^{5}$ cells $\mathrm{l}^{-1}$ following exposure for $2 \mathrm{~d}$ at $\leq 2.0 \mathrm{~m}$ ED and post-UV incubation, approximately 3 times that at low irradiances and $30 \%$ higher than $T_{10}$ controls. Concentrations decreased following longer exposures (4 to $7 \mathrm{~d})$ and were similar to those of $T_{10}$ control treatments. Exposure to low UV irradiances (3.0 and $3.6 \mathrm{~m} \mathrm{ED)} \mathrm{for}$ 1 to $2 \mathrm{~d}$ caused protozoan concentrations following post-UV incubation to decrease to around half that in $T_{10}$ controls. Longer exposures to UV ( $\geq 4 \mathrm{~d}$ ) did not significantly change their concentrations.

While total protozoan cell concentration changed substantially between $T_{0}$ and the $T_{10}$ control treatments, their biomass did not. Mean protozoan biomass following exposure at $\leq 2.0 \mathrm{~m}$ ED and post-UV incubation was commonly greater than in $T_{10}$ control treatments. Their biomass following exposure at 3.0 and $3.6 \mathrm{~m}$ ED was less than $T_{10}$ controls and occasionally less than at $T_{0}$ (Fig. 2D). Protozoan carbon concentrations in treatments exposed to UV at $\leq 2.0 \mathrm{~m}$ ED were commonly 2 to 4 times higher than at 3.0 and $3.6 \mathrm{~m} \mathrm{ED.}$ However, protozoan biomass generally showed high variance due to the occurrence of infrequent large taxa such as dinoflagellates, tintinnids and other ciliates (data not shown) that greatly altered the carbon concentration between replicate fields.

Least squares regression analysis showed a significant negative correlation between total heterotroph and autotroph cell concentrations $(0.002<\mathrm{r}<0.005)$ (Fig. 3). The high variance of calculated carbon biomass confounded any significant correlation between auto- and heterotrophic biomass. No significant correlation existed between the cell concentration or biomass of bacteria (Davidson \& van der Heijden 2000) and phytoplankton or protozoa.

\section{Cell size}

No significant change in ESD of phytoplankton occurred between $T_{0}(12.72 \mu \mathrm{m})$ and the $T_{10}$ control treatments (12.04 $\mu \mathrm{m})$ (Fig. 4). At low UV irradiance (3.6 m ED) the ESD of phytoplankton increased with increasing exposure duration and did not differ significantly from the diameter in $T_{10}$ control treatments following exposures $\geq 2 \mathrm{~d}$ and post-UV incubation. At higher UV irradiances ( $\leq 3.0 \mathrm{~m}$ ED), ESD of phytoplankton were initially similar to that of $T_{10}$ controls but declined with increasing exposure duration and were significantly (around $2 \mu \mathrm{m}$ ) less than the ESD of $T_{0}$ and $T_{10}$ controls following $\geq 2 \mathrm{~d}$ exposure and post-UV incubation.

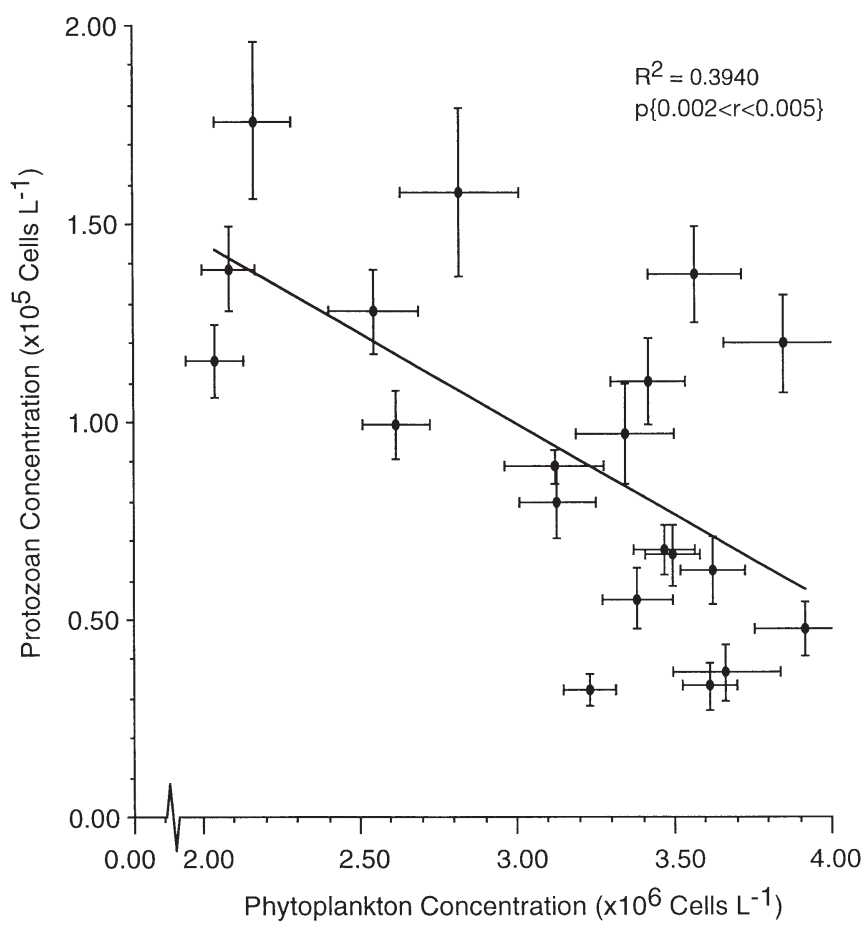

Fig. 3. Least squares regression analysis of phytoplankton and protozoan concentrations exposed to ambient solar irradiances at equivalent water column depths of 1.0, 2.0, 3.0 m and $T_{10}$ control $\geq 20 \mathrm{~m}$ treatments for durations between $8 \mathrm{~h}$ and $7 \mathrm{~d}$ and post-UV incubation (irradiance + post-UV incubation $=10 \mathrm{~d}) . \mathrm{R}^{2}$ is the correlation coefficient of the regression and $\mathrm{p}$ is the probability of the correlation coefficient (2-tailed, $\mathrm{df}=$ 18). Error bars represent \pm 1 standard error 


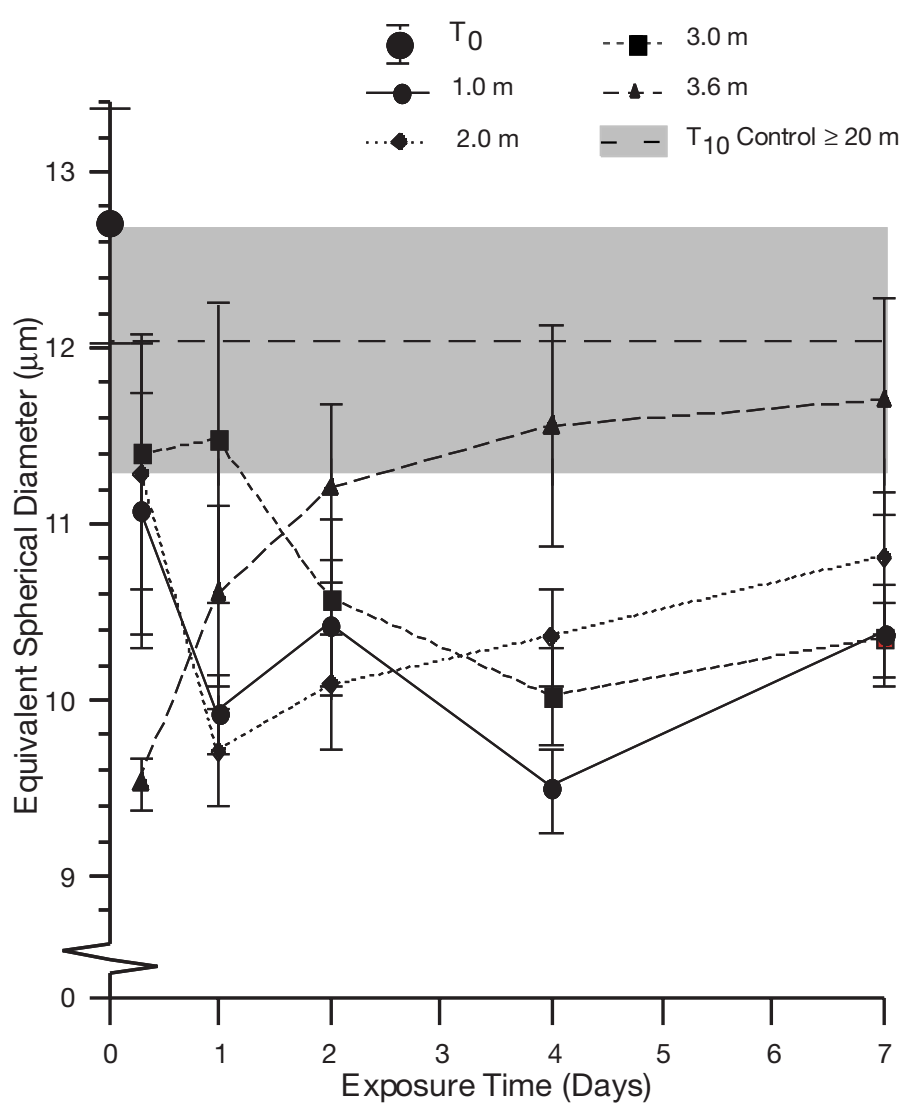

Fig. 4. Equivalent spherical diameter of phytoplankton exposed to ambient solar irradiances at equivalent water column depths of 1.0, 2.0, $3.0 \mathrm{~m}$ and $T_{10}$ control $\geq 20 \mathrm{~m}$ treatments for durations between $8 \mathrm{~h}$ and $7 \mathrm{~d}$ and post-UV incubation (irradiance + post-UV incubation $=10 \mathrm{~d}$ ). Error bars represent \pm 1 standard error. The shadowed area represents \pm 1 standard error for $T_{10}$ controls

UV-induced changes in protozoan cell size were also examined. The size of protozoa in control treatments was significantly lower than that at $T_{0}$. However, due to the lower concentration of protozoa and the occurrence of infrequent large cells, estimates of their ESD in UV-exposed treatments had high variance and seldom differed significantly from $T_{0}$ or control concentrations (data not shown).

\section{Protist species composition}

\section{Phytoplankton}

Fragilariopsis curta (Van Heurck) Krieger and F. cylindrus (Grunow) Krieger constituted around $70 \%$ of the total phytoplankton abundance. While F. curta constituted $>90 \%$ of cells observed in valve view in all light treatments, these species were commonly observed in girdle view and the species could not be separated. Hence they are referred to as $F$. curta/cylindrus.

Some phytoplankton taxa occurred at low concentrations in this study or could not be reliably identified by light microscopy and were therefore grouped. Other diatom spp. contain diatoms that occurred at low abundance, mostly comprising Nitzschia prolongatoides Hasle, Cylindrotheca closterium (Ehrenb.) W. Smith, Chaetoceros dichaeta Ehrenb., Chaetoceros bulbosum (Ehrenb.) Heid. and Pinnularia quadrataria var constricta (Østr.) Heid. Autotrophic nanoflagellates could not reliably be identified by light microscopy but were mostly Pyramimonas gelidicola McFadden, Moestrup and Wetherbee, Geminigera cryophila (Taylor \& Lee) Hill, an unknown Chrysophyte, and mixotrophic Chrysochromulina sp. Autotrophic dinoflagellates were mostly gymnodiniod species.

$T_{0}$ and $T_{10}$ control treatments

The phytoplankton community at $T_{0}$ was dominated by Fragilariopsis curta/cylindrus $\left(1.32 \times 10^{6}\right.$ $\mathrm{1}^{-1}$ ) with Pseudonitzschia subcurvata Hasle subdominant $\left(8.85 \times 10^{5} \mathrm{l}^{-1}\right)$ (Fig. 5). Fragilariopsis pseudonana (Hasle) Krieger, autotrophic nanoflagellates and Thalassiosira ambigua Kozlova were significant contributors to the phytoplankon assemblage $\left(2.31 \times 10^{5} \mathrm{l}^{-1}, 1.83 \times 10^{5} \mathrm{l}^{-1}\right.$ and $1.29 \times$ $10^{5} \mathrm{l}^{-1}$ respectively) while Navicula glaciei Van Heurck, Chaetoceros simplex Ostenfeld, diatom spp. and autotrophic dinoflagellates were minor components $\left(6.76 \times 10^{4}\right.$ to $1.05 \times 10^{4}$ cells $\left.\mathrm{l}^{-1}\right)$.

Changes in the phytoplankton species composition were observed between $T_{0}$ and the $T_{10}$ control treatments. Concentrations of Fragilariopsis curta/cylindrus increased by around $50 \%$ and continued to numerically dominate the community, while concentrations of autotrophic nanoflagellates and Navicula glaciei increased 5- and 16-fold, respectively (Fig. 5A,E,H). Chaetoceros simplex, other diatom spp. and autotrophic dinoflagellates showed little growth (Fig. 5F,G,I) but concentrations of Pseudonitzschia subcurvata, Fragilariopsis pseudonana, and Thalassiosira ambigua declined 83, 61 and 29\%, respectively (Fig. 5B-D).

\section{UV-exposed treatments}

UV-induced mortality of Fragilariopsis curta/cylindrus was responsible for most of the decline in phytoplankton concentrations at high UV irradiances. 

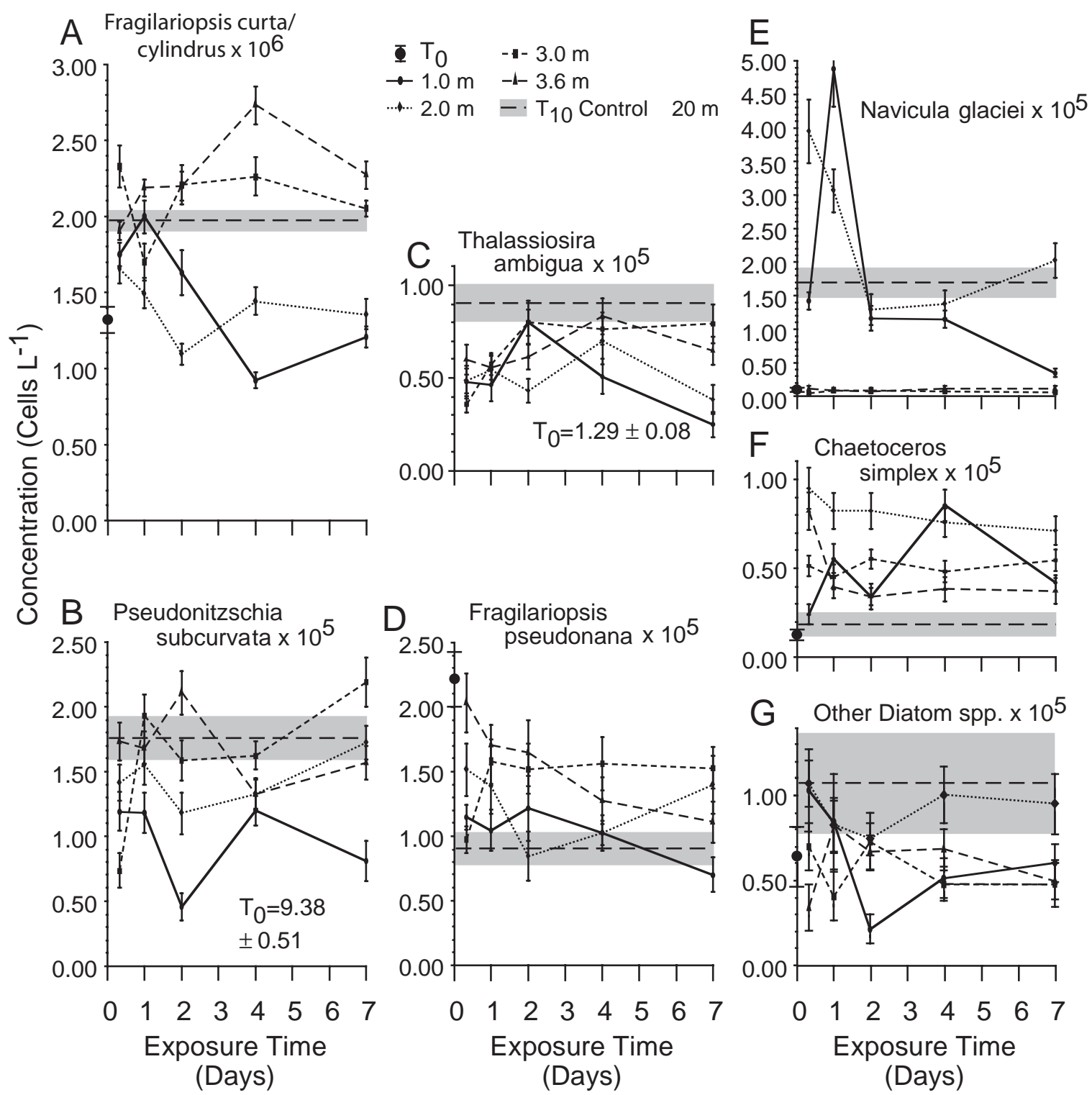

Fig. 5. (Above and following page.) Concentrations of phytoplankton (A to I) and protozoa ( $\mathrm{J}$ to L) following exposure to ambient solar irradiances at equivalent water column depths of 1.0, 2.0,3.0,3.6 m and $T_{10}$ control $\geq 20 \mathrm{~m}$ treatments for durations between $8 \mathrm{~h}$ and $7 \mathrm{~d}$ and post-UV incubation (irradiance + post-UV incubation $=10 \mathrm{~d}$ ). Error bars represent \pm 1 standard error. The shadowed area represents \pm 1 standard error for $T_{10}$ controls. Note different exponents of individual taxa

Concentrations of F. curta/cylindrus declined following exposures at $\leq 2.0 \mathrm{~m}$ ED for between $8 \mathrm{~h}$ and $4 \mathrm{~d}$, after which they remained at or below their $T_{0}$ concentration (Fig 5A). Concentrations F. curta/cylindrus in samples exposed at 3.0 and $3.6 \mathrm{~m}$ ED for $\geq 2 \mathrm{~d}$ exceeded those in the $T_{10}$ control treatments.

Concentrations of Thalassiosira ambigua and Fragilariopsis pseudonana declined to around $50 \%$, and Pseudonitzschia subcurvata to $\leq 20 \%$, of their $T_{0}$ concentrations in all UV-exposed light treatments (Fig. $5 \mathrm{C}, \mathrm{D}, \mathrm{B}$, respectively). Concentrations of these species seldom differed significantly between light treatments but were commonly lowest at $\leq 2.0 \mathrm{~m}$ ED.

In contrast, the diatoms Navicula glaciei Van Heurck and Chaetoceros simplex Ostenfeld showed UVinduced enhancement of cell concentrations (Fig. 5E,F). Exposure of N. glaciei at $\leq 2.0 \mathrm{~m}$ ED for $8 \mathrm{~h}$ to $1 \mathrm{~d}$ caused a dramatic increase in concentration (Fig. 5E). At this time, concentrations were around 25 times higher than that at $T_{0}$ and in low UV treatments (3.0 and $3.6 \mathrm{~m} \mathrm{ED)} \mathrm{and} 2.9$ times higher than the $T_{10}$ controls. Following longer exposures to high UV 

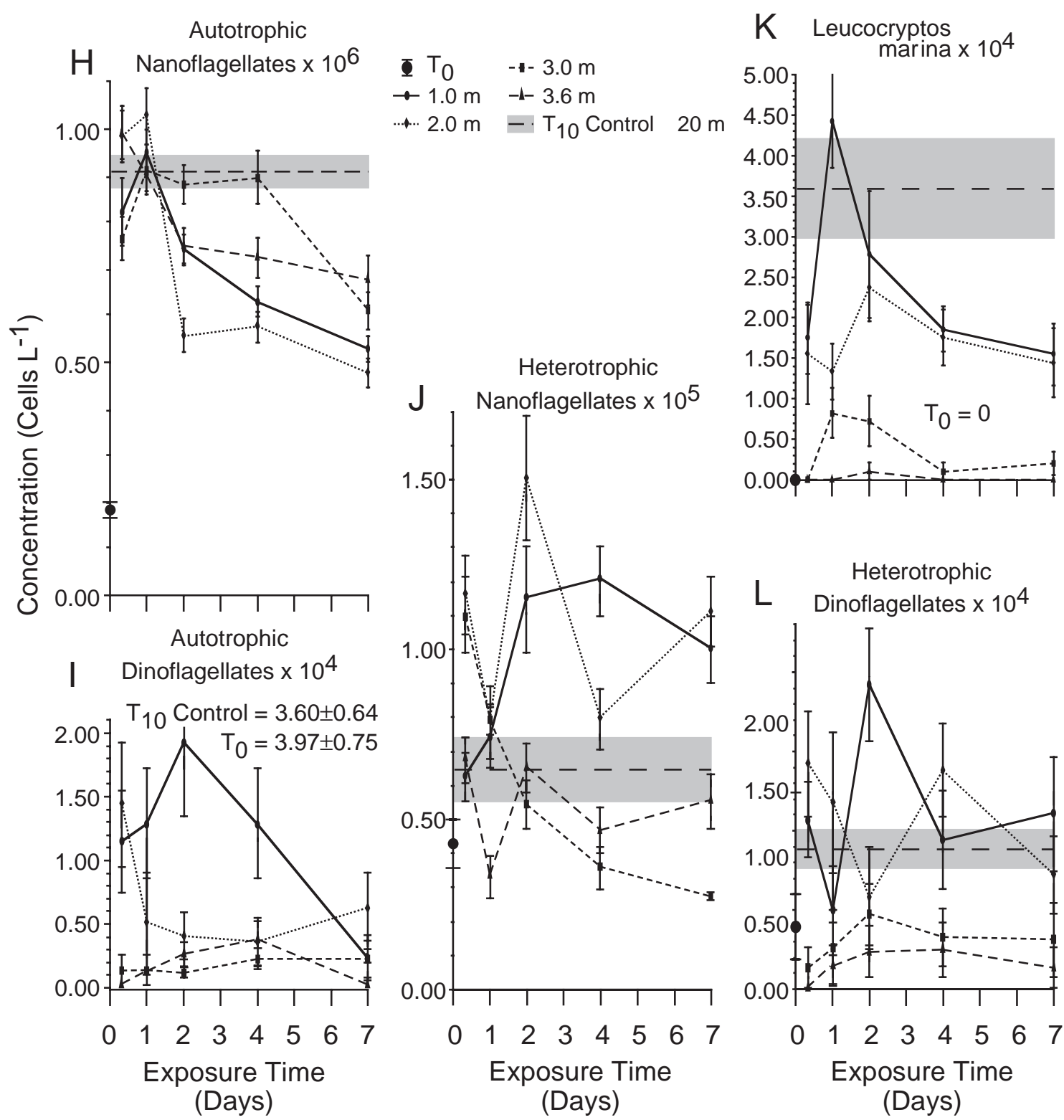

Fig. 5 (continued)

irradiance, $N$. glaciei declined to concentrations that were at or below the $T_{10}$ controls. $N$. glaciei concentrations at 3.0 and $3.6 \mathrm{~m}$ ED did not differ significantly from concentrations at $T_{0}$.

Concentrations of Chaetoceros simplex were, with one exception, significantly higher in UV-exposed treatments than at $T_{0}$ and in the $T_{10}$ controls. Concentrations were highest in treatments exposed to UV at $2.0 \mathrm{~m}$ ED and generally declined with increasing depth of exposure, irrespective of the duration of exposure and post-UV incubation (Fig. 5F). The exception was at $1.0 \mathrm{~m}$ ED, where concentrations peaked after $4 \mathrm{~d}$ exposure, but were generally variable and seldom differed significantly from those at 3.0 and $3.6 \mathrm{~m}$ ED. Concen- trations of other diatoms spp. were variable and seldom differed from the $T_{10}$ control or $T_{0}$ concentrations (Fig. 5G).

Concentrations of autotrophic nanoflagellates did not differ significantly from control treatments following exposure to UV for $\leq 1 \mathrm{~d}$ (Fig. 5H). Longer exposures caused a decline in their concentrations; the rate of this decline generally increased with increasing irradiance.

Concentrations of autotrophic dinoflagellates were generally higher at high UV irradiances (Fig. 5I). At $1.0 \mathrm{~m} \mathrm{ED}$, their concentrations initially increased with increasing exposure duration, reaching a maximum after $2 \mathrm{~d}$ exposure, but declined at longer exposures. Con- 
centrations at $2.0 \mathrm{~m}$ ED were high following $8 \mathrm{~h}$ exposure but declined significantly after exposure for $1 \mathrm{~d}$ and did not change following longer exposures. Following exposure at 3.0 and $3.6 \mathrm{~m} \mathrm{ED}$, concentrations of autotrophic dinoflagellates were low and seldom changed significantly with increased exposure duration.

\section{Protozoa}

Most species of HNAN were not identifiable in fixed samples by light microscopy but included such species as Telonema subtile Griessmann, Thaumatomastix splendida Thomsen, Bicosta antennigera Moestrup and other choanoflagellates species. While ciliates such as tintinnids and Strombidium spp. were observed, counts of these taxa were low, and variances were similar to mean concentrations (data not shown). Heterotrophic dinoflagellate species were principally from the genera Gyrodinium, Protoperidinium, Amphidinium and Prorocentrum.

\section{$T_{0}$ and $T_{10}$ controls}

Concentrations of HNAN and dinoflagellates were low at the beginning of the experiment $\left(T_{0}\right)$, and Leucocryptos marina (Braaud) Butcher was not detected (Fig. 5J-L). Protozoa grew in $T_{10}$ control treatments. HNAN increased from $4.28 \times 10^{4}$ to $6.5 \times 10^{4}$ cells $\mathrm{l}^{-1}$, dinoflagellates increased from $0.39 \times 10^{4}$ to $0.89 \times 10^{4}$ cells $\mathrm{l}^{-1}$, and $L$. marina rose from undetectable to concentrations around $3.52 \times 10^{4}$ cells $\mathrm{l}^{-1}$.

\section{UV-exposed treatments}

The concentration of heterotrophic taxa generally increased following exposure to increasing UV irradiances, but differences were observed in the timing and extent of UV-induced enhancement (Fig. 5J-L). Concentrations of HNAN exposed to UV at $\geq 3.0 \mathrm{~m}$ ED seldom differed significantly from $T_{0}$ or the $T_{10}$ control treatments (Fig. 5J). In contrast, concentrations in treatments exposed at $\leq 2 \mathrm{~m}$ ED for $\geq 2 \mathrm{~d}$ increased 2 - to 4 -fold.

Leucocryptos marina grew in all UV-exposed treatments; however, only after 1 to $2 \mathrm{~d}$ exposure at $1.0 \mathrm{~m}$ ED and post-UV incubation did concentrations reach that in $T_{10}$ controls (Fig. 5K). Maximum concentrations occurred after 1 to 2 d exposure in all UV treatments but declining thereafter. Concentrations of L. marina exposed at 3.0 and $3.6 \mathrm{~m}$ ED were low, seldom changed significantly with exposure duration, and were only 5 to $20 \%$ of that in treatments at $\leq 2.0 \mathrm{~m} \mathrm{ED}$.
Counts of the heterotrophic dinoflagellates had large standard errors due to their low concentrations (Fig. 5L). While their concentrations were commonly higher in treatments exposed at $\leq 2.0 \mathrm{~m} \mathrm{ED}$, they seldom differed significantly from $T_{10}$ control treatments. At depths $\geq 3.0 \mathrm{~m}$ their concentrations did not differ significantly from those at $T_{0}$ and were around $30 \%$ of that in high UV treatments.

\section{Statistical analyses}

Statistical analyses were performed to determine patterns and relationships between the UV irradiance (ED), exposure duration and species composition.

\section{Exploratory statistics}

Cluster analysis, based solely on the protist species composition of the 375 replicate microscope field counts, distinguished 7 groups at a dissimilarity of 0.54 that conveniently summarised changes in the microbial species composition. Two of these clusters were due to the absence of Thalassiosira ambigua, dinoflagellates or Leucocryptos marina, had $\leq 10$ field counts per cluster group, and were not considered further (Fig. 6 dotted lines).

We also examined the light treatment (ED and exposure duration) received by microscope field counts contained in each of the cluster groups above. The frequency of each light treatment in each cluster group was calculated, and the frequency distribution of exposure depths and durations were plotted beside each of the cluster groups (Fig. 6A-J).

Dissimilarity of the 5 cluster groups (Fig. 6 numbers 1 to 4,6 enclosed by squares) showed that there were 3 subgroups. Cluster group 1 comprised control treatments ( $\geq 20 \mathrm{~m} \mathrm{ED)}$ and brief exposures to high UV (Fig. 6A,B). The group was characterised by moderate concentrations of all protist taxa and highest concentrations of autotrophic dinoflagellates and Leucocryptos marina. The species composition of this group was more similar to cluster groups 2 to 4 , which contained treatments exposed to high ( $\leq 2.0 \mathrm{~m}$ ED) UV irradiance, than to groups that contained treatments exposed to low (3.0 and 3.6 m ED) UV irradiance due to the high concentrations of protozoan taxa (see Protozoa: $T_{0}$ and $T_{10}$ controls).

Cluster groups 2 to 4 contained microscope field counts from treatments exposed to high UV irradiances ( $\leq 2.0 \mathrm{~m}$ ED) (Fig. 6D,F,H). These groups differed little, with a dissimilarity of 0.03 between cluster groups 2 and 3 , and between groups 3 and 4 . High UV-irradiance treatments were characterised by high concentrations 


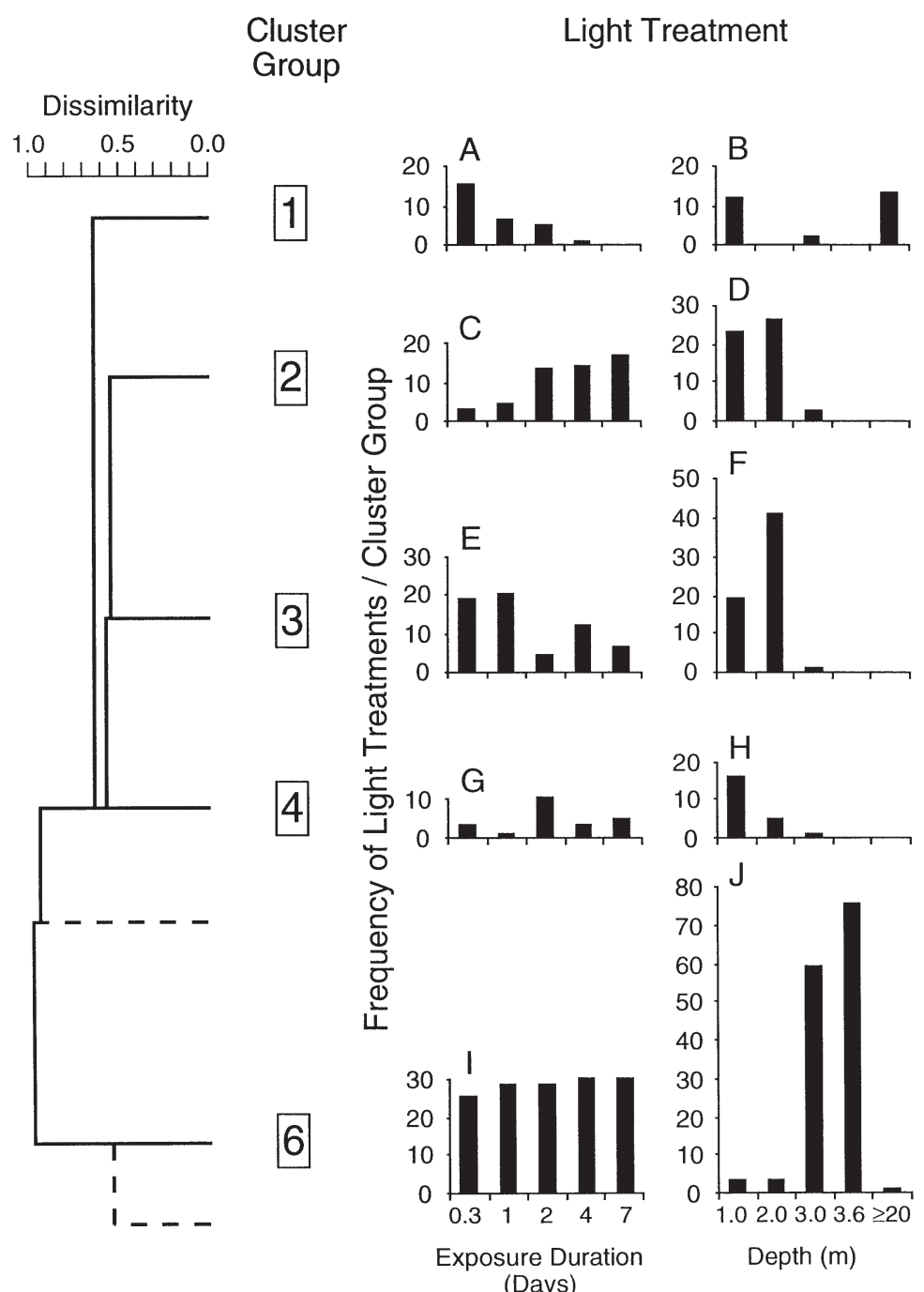

Fig. 6. Seven cluster groups, which conveniently summarised the changes in microbial species composition of individual microscope-field counts, were obtained at a dissimilarity of 0.54 . Dotted lines denote cluster groups containing $\leq 10$ replicate field counts that are not considered in detail. The numbers 1 to 4 and 6 enclosed in rectangles denote the 5 remaining cluster groups. The frequency of UV treatments (durations and equivalent depths of UV exposure) received by the microscope fields in each cluster group is presented beside each cluster group (A to J)
Fragilariopsis curta/cylindrus, low autotrophic flagellates concentrations and high concentrations of Chaetoceros simplex and HNAN. Cluster group 3 mostly contained field counts exposed to high UV $(\leq 2.0 \mathrm{~m})$ for $\leq 1$ d (Fig. 6E,F). This group was characterised by concentrations of the F. curta/ cylindrus, Pseudonitzschia subcurvata, and Fragilariopsis pseudonana that were similar to those of group 6 (see below) but had the highest concentrations of Navicula glaciei and $C$. simplex, and had higher concentrations of HNAN and Leucocryptos marina than at 3.0 and $3.6 \mathrm{~m} \mathrm{ED}$, respectively. Cluster group 4 contained 22 field counts, most of which had been exposed at 1 $\mathrm{m}$ ED for $2 \mathrm{~d}$ but included some other exposure durations (Fig. 6G,H). This group was characterised by low concentrations of the diatoms F. curta/cylindrus, P. subcurvata and F. pseudonana, and high concentrations of heterotrophic dinoflagellates.

Cluster group 6 contained all microscope field counts exposed at 3.0 and $3.6 \mathrm{~m}$ ED, indicating a consistent change in species composition irrespective of exposure duration (Fig. 6I,J). This cluster group was characterised by high concentrations of the diatom species Fragilariopsis curta/cylindrus, Pseudonitzschia subcurvata, F. pseudonana and Thalassiosira ambigua and low concentrations of Leucocryptos marina, HNAN, and auto- and heterotrophic dinoflagellates.

\section{Confirmatory statistics}

MANOVA showed that UV irradiance (ED), exposure duration and the interaction of the two caused highly significant changes in protistan species composition $\left(\mathrm{p}_{\mathrm{F}}<0.001\right)$

(Table 2). UV irradiance alone caused a of Navicula glaciei, other diatom spp., auto- and heterotrophic dinoflagellates Leucocryptos marina and HNAN, but low concentrations of Fragilariopsis curta/ cylindrus, Pseudonitzschia subcurvata and Thalassiosira ambigua. Subdivision of the high UV-irradiance treatments into cluster groups 2 to 4 generally correlated with the duration of UV exposure, indicating that changes in exposure duration generated different species compositions (Fig. 6C,E,G).

Cluster group 2 contained field counts exposed to high UV ( $\leq 2.0 \mathrm{~m}$ ) for 2 to $7 \mathrm{~d}$ (Fig. 6C,D). This group was characterised by the lowest concentrations of significant change in the concentration between protist taxa and within each taxon (parametric and nonparametric $\mathrm{p}_{\mathrm{F}}<0.001$ ) (Table 2). Exposure duration was responsible for significant changes in the concentration between protist species but also caused significant changes in the concentrations of Pseudonitzschia subcurvata, Navicula glaciei, Thalassiosira ambigua, diatom spp., autotrophic flagellates and Leucocryptos marina $\left(\mathrm{p}_{\mathrm{F}}<0.05\right)$. The interaction effect of irradiance and duration together was significant between species and for each species $\left(\mathrm{p}_{\mathrm{F}}<0.03\right)$ except diatom spp. and auto- and heterotrophic dinoflagellates (Table 2). 
Table 2. Probability obtained by 2-way multivariate analysis of variance (MANOVA) of the relativised concentrations of all protist species showing the non-parametric probability (Wilks' lambda) between species and within (F-test) probabilities of changes in concentration of each species resulting from the individual effects (equivalent depth [ED], duration of UV exposure) and their interaction. Summary of all effects gave a non-parametric probability of $<0.0005$

\begin{tabular}{|lccc|}
\hline Source & ED & Duration & $\begin{array}{c}\text { Interaction: } \\
\text { ED } \times \text { Duration }\end{array}$ \\
\hline Between species & & & 0.000 \\
Fragilariopsis curta/cylindrus & 0.000 & 0.000 & 0.000 \\
Pseudonitzschia subcurvata & 0.000 & 0.102 & 0.000 \\
Fragilariopsis pseudonana & 0.000 & 0.221 & 0.001 \\
Navicula glaciei & 0.000 & 0.000 & 0.000 \\
Thalassiosira ambigua & 0.000 & 0.002 & 0.001 \\
Chaetoceros simplex & 0.000 & 0.089 & 0.000 \\
Diatom spp. & 0.000 & 0.015 & 0.277 \\
Autotrophic dinoflagellates & 0.000 & 0.654 & 0.555 \\
Autotrophic flagellates & 0.000 & 0.000 & 0.000 \\
Leucocryptos marina & 0.000 & 0.000 & 0.027 \\
Heterotrophic dinoflagellates & 0.000 & 0.639 & 0.180 \\
Heterotrophic flagellates & 0.000 & 0.689 & 0.000 \\
\hline
\end{tabular}

\section{DISCUSSION}

Natural plankton communities comprise a complex web of trophic interactions; however, scientific attention has focused on the impact of UV on phytoplankton. Remarkably little is known about the effect of UVB on marine microbial communities. The few studies that have examined UV-induced changes to marine communities are from the northern hemisphere. Their findings indicate that the impact of UV radiation on planktonic communities range from insignificant or small in comparison with natural variability (Halac et al. 1997, Keller et al. 1997a,b, Laurion et al. 1998) to major changes in the structure and function of the pelagic food web (Wickham \& Carstens 1998, Mostajir et al. 1999, Sommaruga et al. 1999). Our results show that UV can change the trophic structure and species composition of the marine microbial community.

Exposure of microbial assemblages to UV for between $8 \mathrm{~h}$ and $7 \mathrm{~d}$ was chosen because shallow mixed depth in the marginal ice zone may persist for around 6 d (Mitchell \& Holm-Hansen 1991, Veth 1991). Biologically significant UVB irradiances can penetrate to $>20 \mathrm{~m}$ depth in Antarctic waters (Karentz \& Lutze 1990, Smith et al. 1992). Thus, exposure durations used in this experiment were ecologically sustainable. Similar to Davidson et al. (1996), we included post-UV incubation in our experiments. As the total duration of UV exposure plus post-UV incubation was $10 \mathrm{~d}$, samples exposed to UV for different exposure periods necessarily had different recovery periods. However, our experimental design incorpo- rated photoadaptation and photorepair in response of microbial assemblages to UV exposure, allowed expression of UV-induced changes in the microbial species composition (especially following brief UV exposures), and allowed statistical analysis of the results using cell concentrations since they all received the same total period of growth.

\section{Total protists}

Phytoplankton and protozoa grew during the experiments. Phytoplankton increased in $T_{10}$ control treatments and samples exposed to UV at 3.0 and $3.6 \mathrm{~m}$ ED compared with $T_{0}$ concentrations. Protozoan concentrations also increased in all treatments and $T_{10}$ controls, but increases were greatest in control and high UV treatments. However, large overall differences in the concentrations of protists were observed between light treatments.

\section{Phytoplankton}

Numerous authors report that the growth, survival and production of phytoplankton are reduced by exposure to UV radiation (for reviews see Davidson 1998, Vernet 2000). We found that exposure to Antarctic solar UV radiation at 3.0 and $3.6 \mathrm{~m}$ ED caused no significant inhibition of phytoplankton concentration in comparison with $T_{10}$ controls, but prolonged exposure to high UV irradiances $(\geq 2 \mathrm{~d}$ at $\leq 2.0 \mathrm{~m}$ ED) caused substantial mortality of phytoplankton. The extent of phytoplankton mortality was dependent on the irradiance (ED) and exposure duration. Thus, phytoplankton concentrations were determined by UV dose and dose rate. Villafañe et al. (1995) and Davidson et al. (1996) found that community-based acclimation maintained the overall biomass of UV-exposed phytoplankton assemblages. Similar to McMinn (1997), we found that exposure to high UV irradiances reduced phytoplankton biomass over the duration of the experiment. This was probably due to the UV sensitivity of the dominant species in the community we examined, the extent to which the species composition changed to attain an appropriate level of UV tolerance and the time allowed for acclimation of the community composition to UV exposure (Villafañe et al. 1995). 


\section{Protozoa}

Similar to Chatila et al. (1999) and Mostajir et al. (1999), we found that protozoan concentrations and biomass increased at high UV irradiances. UVB can impair cell orientation, flagella motion and feeding currents, and may cause mortality of many protozoa (e.g. Sommaruga et al. 1996, Ochs 1997, Chatila et al. 1999, Mostajir et al. 1999). However, Chatila et al. (1999) found that the UV tolerance of protozoans increased with increasing nutrient concentrations. In our study, survival and growth of protozoa were enhanced at high UV irradiances and coincided with increased phytoplankton mortality (see below). UVinduced inhibition of protozoa may have occurred at irradiances that were insufficient to cause phytoplankton mortality (see below). Such inhibition may explain why protozoan concentrations were lower at 3.0 and $3.6 \mathrm{~m}$ ED than in $T_{10}$ controls and why control treatments were not more closely associated with treatments exposed to low UV irradiances in cluster analysis

Interactions

A significant negative correlation was found between the total concentrations of phytoplankton and protozoa in UV-exposed treatments. Death of phytoplankton following exposure at $\leq 2.0 \mathrm{~m}$ ED for $\geq 2 \mathrm{~d}$ resulted in a significant decline in the concentrations of calculated phytoplankton cell carbon. Thus, mortality released substantial concentrations of particulate and dissolved organic carbon. Phytoplankton mortality coincided with an increase in protozoan concentrations, due largely to increases in Leucocryptos marina, Thaumatomastix splendida, Telonema subtile, Bicosta antennigera and an unknown heterotrophic flagellate. Such taxa reportedly consume detrital matter, nanoplankton, bacteria and dissolved organic carbon (Vørs 1992, Marchant \& Scott 1993, Thomsen \& Ikavalko 1997, Brandt \& Sleigh 2000, M. Sieracki pers. comm.). The negative correlation we observed between the concentrations of phytoplankton and those of protozoa may have been due to UV-induced mortality of phytoplankton that increased the nutrition availability for protozoa, increasing their UV tolerance (Chatila et al. 1999) and supporting their growth. Thus, similar to Chatila et al. (1999) and Mostajir et al. (1999), it is likely that indirect effects of UV on the microbial trophodynamics enhanced the concentrations of protozoa rather than direct enhancement of protozoans by exposure to UV radiation.

Concentrations of bacteria in this study were similar between treatments exposed to high and low UV
(Davidson \& van der Heijden 2000) despite substantial phytoplankton mortality. Senescence and mortality of phytoplankton can enhance growth of bacterioplankton (e.g. Kirchman 1999), and UVB radiation can photodegrade dissolved organic matter (DOM) to smaller molecules that are more available to bacteria and promote their growth (Herndl et al. 1997, Kaiser \& Herndl 1997). UV radiation can also inactivate viruses that are thought to be a major cause of bacterial mortality (Suttle \& Chen 1992, Murray \& Jackson 1993). However, bactivorous grazers may mediate UVinduced enhancement of bacterioplankton. Protozoan grazing of bacteria is a major route for carbon in the marine ecosystem, returning carbon from the dissolved organic carbon pool to the food chain via the microbial loop (Azam 1998). Bactivory can limit the concentration of bacteria by grazing the new production (e.g. Becquevort et al. 2000). Gustavson et al. (2000) found that enhanced UVB probably increased bacterial activity, but that this was matched by increased rates of bactivory. Together with the increase in protozoan concentrations we observed in high UV treatments, this may explain the absence of any increase in bacterial concentration in our study.

\section{Species composition}

Cluster analysis, based solely on protist species composition, formed cluster groups that corresponded to the experimental light treatments from which the replicate microscope field counts were obtained. Thus, most of the changes in species composition were due to the light treatment.

\section{Phytoplankton}

Changes in phytoplankton species composition were observed between $T_{0}$ and the $T_{10}$ control treatments. While the total concentration of phytoplankton increased (see above) and Fragilariopsis curta/cylindrus maintained dominance in the $T_{10}$ controls, the relative contribution by many subdominant diatom species declined (e.g. Pseudonitzschia subcurvata, Fragilariopsis pseudonana and Thalassiosira ambigua). These species were replaced by increases in the relative concentrations of autotrophic nanoflagellates, Navicula glaciei and other diatom spp. Thus, experimental incubation exerted a species-selective force that was independent of UV exposure. Such changes are likely due to differences between the environment at the collection site $(10 \mathrm{~m}$ depth beneath $1.7 \mathrm{~m}$ of snow-covered sea ice) and near-surface exposure to wavelengths $>375 \mathrm{~nm}$. 
There is a growing body of evidence that interspecific differences in UV tolerance cause changes in the species composition of natural marine phytoplankton assemblages exposed to UV radiation (Smith et al. 1992, Wängberg et al. 1996, McMinn 1997, Laurion et al. 1998). Similarly, we found that following UV exposure, some species died, some flourished, while others were unaffected. MANOVA showed that the UV irradiance (dose rate) changed the phytoplankton species composition, significantly changing the concentrations of every taxon.

The integrated UV dose also changed the phytoplankton species composition as many phytoplankton taxa showed significant changes in concentrations as a result of exposure duration. However, our results also suggest photoacclimation to UV exposure by some phytoplankton taxa. The concentrations of Fragilariopsis curta/cylindrus, Fragilariopsis pseudonana, Pseudonitzschia subcurvata and Chaetoceros simplex differed between UV irradiances (ED), indicating that exposure to high UV irradiances caused inhibition or mortality of these species. However, MANOVA showed that their concentration did not change significantly with changes in exposure duration. Those taxa that survived brief exposures to high UV irradiances $(\leq 2 \mathrm{~d}$ at $\leq 2.0 \mathrm{~m}$ ED) also survived prolonged exposures $(7 \mathrm{~d})$. UV tolerance mechanisms may have changed the sensitivity of phytoplankton to UV exposure wavelengths (Cullen \& Lesser 1991, Karentz et al. 1991, Helbling et al. 1992). Little is known about variation in UV tolerance within phytoplankton species, but our data suggest that selection of UV-tolerant strains may also contribute to persistence of some species in UVexposed communities.

Attempts have been made to categorise the sensitivity of phytoplankton to UVB radiation on broad taxonomic criteria or cell size (e.g. Karentz et al. 1991, Villafañe et al. 1995, Helbling et al. 1996). Karentz et al. (1991) observed an increase in UV-induced damage with decreasing cell size. In contrast, we observed an overall decrease in the ESD of phytoplankton cells with increased UV irradiance. Thus, small species had a greater UV tolerance than larger species, recovered faster or grew more rapidly during the post-UV incubation. Alternatively, UV-induced changes in the protozoan community may have altered size-selective grazing on the phytoplankton community.

We also found large interspecific differences in UV tolerance within broad taxonomic criteria. Exposure to high UV ( $\leq 2.0 \mathrm{~m}$ ED) caused concentrations of such diatoms as Fragilariopsis curta/cylindrus and Fragilariopsis pseudonana to decline, while diatoms of similar cell size such as Navicula glaciei and Chaetoceros simplex respectively increased in these treatments. Such species-specific variation is likely to defy any attempts to resolve differences in UV tolerance between broad taxonomic criteria. Thus, similar to other studies (Davidson et al. 1996, Wängberg et al. 1996, McMinn 1997, Laurion \& Vincent 1998, Mostajir et al. 1999), we could not categorise the UV tolerance of the phytoplankton species based on cell size or taxonomic affinity.

\section{Protozoa}

The concentrations of all 3 protozoan taxa increased between $T_{0}$ and the $T_{10}$ control treatments. Leucocryptos marina greatly increased its contribution to the protozoan community, rising from negligible concentrations at $T_{0}$ to become the second most abundant species in $T_{10}$ control and high UV-irradiance treatments.

We found that concentrations of all 3 protozoan taxa were highest following exposure to high UV irradiances. Protozoans reportedly differ greatly in their sensitivity to UV exposure (Sommaruga \& Buma 2000). Mostajir et al. (1999) found that changes in the composition and abundance of protozoan species were due to differences in the UV tolerance. However, we found enhanced concentrations of all the protozoan taxa, which correlated with the mortality of the phytoplankton. We proposed (see above) that UV-induced phytoplankton mortality increased nutrition for protozoa, enhancing their UV tolerance (Chatila et al. 1999) and fuelling their growth. However, MANOVA showed that the response of each protozoan taxon differed in relation to the UV treatment.

Concentrations of all protozoan taxa differed significantly between UV irradiances (ED). However, only Leucocryptos marina changed significantly in concentration as a result of exposure duration, while concentrations of heterotrophic dinoflagellates did not change significantly in the interaction of irradiance and exposure duration. The reasons for differences between light treatments are unclear but may have been due to: the statistical variance of the counts (especially dinoflagellates); UV-induced changes in species composition within heterotrophic dinoflagellates and HNAN; changes in the quality or quantity of their food due to UV irradiance and duration; or UV-induced inhibition of protozoa growth and survival.

\section{Interactions}

Changes in protist species composition during the first 1 to $2 \mathrm{~d}$ of UV exposure, when phytoplankton mortality is at its highest, are erratic and difficult to predict. During this apparently chaotic state, UV-tolerant 
opportunistic species of phytoplankton and protozoa such as Navicula glaciei and Leucocryptos marina can greatly increase their contribution to the marine microbial community. However, similar to Davidson et al. (1996), we found that UV-induced changes in the community had largely been determined following exposure for $>2 \mathrm{~d}$. Thereafter, the community persisted with relatively little change as a result of increased exposure duration.

In conclusion, our results show that ambient Antarctic UV changed the species composition of natural marine microbial assemblages. The magnitude of these changes appears related to the sensitivity of the individual species that constitute the community and the extent to which these species are key determinants of the community structure and function. The effect of the UV-induced changes on the community were dependent on the UV irradiance, duration of exposure and sensitivity of the component species, resulting in a complex mosaic of changing abundance. Changes were initially chaotic but developed clear patterns of changing community structure and function with increasing exposure duration. UV-induced mortality of phytoplankton was a key determinant of protist abundance and species composition. While we only observed phytoplankton mortality at depths $\leq 2.0 \mathrm{~m}$ following exposure for 1 to $2 \mathrm{~d}$, biologically significant UVB irradiances can penetrate to $>20 \mathrm{~m}$ depth in Antarctic waters (Karentz \& Lutze 1990, Smith et al. 1992) and UVB can cause mortality of phytoplankton to $10 \mathrm{~m}$ depth (Karentz 1989). Blooms of marine microbes in the sea ice and marginal ice zone during spring contribute much of the production in the Southern Ocean (Smith \& Nelson 1986, Voytek 1989) but coincide with ozone depletion in spring and early summer and occur in environments that are penetrated by UVB radiation (Davidson 1998). Our results show that enhanced UV may significantly affect the species composition of Antarctic protist communities. Such changes could alter size, availability, palatability and nutritional value of food available to higher trophic levels (Vincent \& Roy 1993). We also found UVinduced inhibition and mortality of phytoplankton, and previous studies have shown that UVB exposure reduced the rate at which carbon is sequestered by photosynthesis (e.g. Smith et al. 1992, Helbling et al. 1992). Bacterial concentrations in our study did not change, but UV-induced phytoplankton mortality directly or indirectly enhanced the abundance of protozoa. We propose that respiration by these organisms, together with reduced phytoplankton production, could increase concentrations of $\mathrm{CO}_{2}$ in nearsurface waters and reduce vertical carbon flux, exacerbating accumulation of greenhouse $\mathrm{CO}_{2}$ in the atmosphere.
Acknowledgements. We gratefully acknowledge Colin Roy and Peter Geis from the Australian Radiation Protection and Nuclear Safety Agency for kindly providing UV-biometer data. We also wish to thank Kelvin Michael for advice regarding UV measurements, Simon Wright for his advice on programming, and S. Wright and $\mathrm{H}$. Marchant for their constructive criticism of this manuscript.

\section{LITERATURE CITED}

Azam F (1998) Microbial control of oceanic carbon flux: the plot thickens. Science 280:694-696

Becquevort S, Menon P, Lancelot C (2000) Differences of the protozoan biomass and grazing during spring and summer in the Indian sector of the Southern Ocean. Polar Biol 23: 309-320

Belbin L (1993) PATN technical reference manual. CSIRO Division of Wildlife and Ecology, Canberra, p 1-234

Belbin L, Faith DP, Milligan GM (1992) A comparison of two approaches to better flexible clustering. Multivar Behav Res 27:417-433

Børsheim KY, Bratbak G (1987) Cell volume to cell carbon conversion factors for a bacterivorous Monas sp. enriched from seawater. Mar Ecol Prog Ser 36:171-175

Bothwell ML, Sherbot D, Pollock CM (1994) Ecosystem response to solar ultraviolet-B radiation: influence of trophic level interactions. Science 265:97-100

Brandt SM, Sleigh MA (2000) The qualitative occurrence of different taxa of heterotrophic flagellates in Southampton Water, UK. Est Coast Shelf Sci 51:91-102

Bray JR, Curtis JT (1957) An ordination of the upland forest communities of southern Wisconsin. Ecol Monogr 27: 325-349

Caron DA, Dam HG, Kremer P, Lessard EJ, and 6 others (1995) The contribution of microorganisms to particulate carbon and nitrogen surface waters or the Sargasso Sea near Bermuda. Deep-Sea Res 42:943-972

Chatila K, Demers S, Mostajir B, Gosselin M, Chanut JP, Monfort P (1999) Bactivory of a natural heterotrophic protozoan community exposed to different intensities of ultraviolet-B radiation. Aquat Microb Ecol 20:59-74

Cullen JJ, Lesser MP (1991) Inhibition of photosynthesis by ultraviolet radiation as a function of dose and dose rate: results for a marine diatom. Mar Biol 111:183-190

Davidson AT (1998) The impact of UVB radiation on marine plankton. Mutation Res 422:119-129

Davidson AT, van der Heijden A (2000) Exposure of natural Antarctic marine microbial assemblages to ambient UV radiation: effects on bacterioplankton. Aquat Microb Ecol 21:257-264

Davidson AT, Marchant HJ, de la Mare WK (1996) Natural UVB exposure changes the species composition of Antarctic phytoplankton in mixed culture. Aquat Microb Ecol 10: 299-305

Dehairs F, Geoyens L, Stroobants N, Mathot S (1992) Elemental composition in the Weddell-Scotia confluence area during spring and summer 1988 (EPOS Leg 2). Polar Biol 12:25-33

Field JG, Clarke KR, Warwick RM (1982) A practical strategy for analysing mutlispecies distribution patterns. Mar Ecol Prog Ser 8:37-52

Frederick JE, Lubin D (1994) Solar ultraviolet radiation at Palmer Station, Antarctica. In: Weiler CS, Penhale PA (eds) Ultraviolet radiation in Antarctica. Measurements and biological effects. Antarctic research series, Vol 62. American Geophysical Union, Washington, DC, p 43-52 
Gustavson K, Garde K, Wängberg SÅ, Selmer JS (2000) Influence of UV-B radiation on bacterial activity in coastal waters. J Plankton Res 22:1501-1511

Halac S, Felip, M, Camarero L, Sommaruga-Wögrath S, Psenner R, Catalan J, Sommaruga R (1997) An in situ enclosure experiment to test the solar UVB impact on phytoplankton in a high-altitude mountain lake. Lack of effect on phytoplankton species composition and growth. J Plankton Res 19:1671-1686

Helbling EW, Villafañe V, Ferrario M, Holm-Hansen O (1992) Impact of ultraviolet radiation on specific marine phytoplankton species. Mar Ecol Prog Ser 80:89-100

Helbling EW, Chalker BE, Dunlap WC, Holm-Hansen O, Villafañe VE (1996) Photoacclimation of antarctic marine diatoms to solar ultraviolet radiation. J Exp Mar Biol Ecol 204:85-101

Herndl GJ, Brugger A, Hager S, Kaiser E, Obernosterer I, Reitner B, Slezak D (1997) Role of ultraviolet-B radiation on bacterioplankton and the availability of dissolved organic matter. Plant Ecol 128:42-51

Jeffrey WH, Kase JP, Wilhelm SW (2000) UV radiation effects on heterotrophic bacterioplankton and viruses in marine ecosystems. In: de Mora S, Demers S, Vernet M (eds) The effects of UV radiation in the marine environment. Cambridge environmental chemistry series, Vol 10. Cambridge University Press, Cambridge, p 206-236

Jones AE, Shanklin JD (1995) Continued decline of ozone over Halley, Antarctica, since 1985. Nature 376:409-411

Kaiser E, Herndl GJ (1997) Rapid recovery of marine bacterioplankton activity after inhibition by UV radiation in coastal waters. Appl Environ Microbiol 63:4026-4031

Karentz D (1989) Report on studies related to the ecological implications of ozone depletion on the Antarctic environment. Antarct J US 23:114-115

Karentz D (1994) Ultraviolet tolerance mechanisms in Antarctic marine organisms. In: Weiler CS, Penhale PA (eds) Ultraviolet radiation in Antarctica. Measurements and biological effects. Antarctic research series, Vol 62. American Geophysical Union, Washington, DC, p 93-110

Karentz D, Lutze LH (1990) Evaluation of biologically harmful radiation in Antarctica with a biological dosimeter designed for aquatic environments. Limnol Oceanogr 35: 549-561

Karentz D, Cleaver JE, Mitchell DL (1991) Cell survival characteristics and molecular responses of Antarctic phytoplankton to ultraviolet-B radiation. J Phycol 27:326-341

Keller A, Hargraves P, Jeon H, Klein-Macphee, Klos E, Oviatt C, Zhang J (1997a) Ultraviolet-B radiation enhancement does not affect marine trophic levels during a winterspring bloom. Ecoscience 4:129-139

Keller A, Hargraves P, Jeon H, Klein-Macphee, Klos E, Oviatt C, Zhang J (1997b) Effects of ultraviolet-B enhancement on marine trophic levels in a stratified coastal system. Mar Biol 130:277-287

Kerr RA (1998) Deep chill triggers record ozone hole. Science 282:391

Kirchman DL (1999) Phytoplankton death in the sea. Nature 398:293-294

Kirk JTO (1983) Light and photosynthesis in aquatic ecosystems. Cambridge University Press, Cambridge

Klein Breteler WCM (1985) Fixation artifacts of phytoplankton in zooplankton grazing experiments. Hydrobiol Bull 19:922-929

Laurion I, Vincent WF (1998) Cell size versus taxonomic composition as determinants of UV-sensitivity in natural phytoplankton communities. Limnol Oceanogr 43: $1774-1779$
Laurion I, Lean DRS, Vincent WF (1998) UVB effects on a phytoplankton community: results from a large-scale enclosure assay. Aquat Microb Ecol 16:189-198

Marchant HJ, Scott FJ (1993) Uptake of sub-micrometre particles and dissolved organic material by Antarctic choanoflagellates. Mar Ecol Prog Ser 92:59-64

McMinn A (1997) Species succession in fast ice algal communities: a response to UV-B radiation? Korean J Polar Res 8: $47-52$

Mitchell BG, Holm-Hansen O (1991) Observations and modelling of the Antarctic phytoplankton crop in relation to mixing depth. Deep-Sea Res 38:981-1007

Montagnes DJS, Berges JA, Harrison PJ, Taylor FJR (1994) Estimating carbon, nitrogen, protein, and a chlorophyll a from volume in marine phytoplankton. Limnol Oceanogr 39:1044-1060

Mostajir JB, Demers S, de Mora SJ, Belzile C, and 6 others (1999) Experimental test of the effect of ultraviolet-B radiation in a planktonic community. Limnol Oceanogr 44: 586-596

Mostajir JB, Demers S, de Mora SJ, Bukata RP, Jerome JH (2000) Implications of UV radiation for the food web structure and consequence for carbon flow. In: de Mora $\mathrm{S}$, Demers $\mathrm{S}$, Vernet $\mathrm{M}$ (eds) The effects of UV radiation in the marine environment. Cambridge environmental chemistry series, Vol 10. Cambridge University Press, Cambridge, p 310-320

Murray AG, Jackson GA (1993) Viral dynamics: a model of the interaction of ultraviolet light and mixing processes on virus survival in seawater. Mar Ecol Prog Ser 102:105-114

Ochs CA (1997) Effects of UV radiation on grazing by two marine heterotrophic nanoflagellates on autotrophic picoplankton. J Plankton Res 19:1517-1536

Ohman MD, Snyder RA (1991) Growth kinetics of the omnivorous oligotrich ciliate, Strombidium sp. Limnol Oceanogr 36:922-935

Putt M, Stoeker DK (1989) An experimentally determined carbon:volume ratio for marine 'oligotrichous' ciliates from estuarine and coastal waters. Limnol Oceanogr 34: 1097-1103

Ryan KG, Beaglehole D (1994) Ultraviolet radiation and bottom ice algae: laboratory and field studies from McMurdo Sound, Antarctica. In: Weiler CS, Penhale PA (eds) Ultraviolet radiation in Antarctica. Measurements and biological effects. Antarctic research series, Vol 62. American Geophysical Union, Washington, DC, p 229-242

Sherr EB, Sherr BF (1993) Preservation and storage of samples for enumeration of heterotrophic protists. In: Kemp PF, Sherr BF, Sherr EB, Cole JJ (eds) Handbook of methods in aquatic microbial ecology. Lewis Publishers, Boca Raton, p 207-212

Smith WO Jr, Nelson DM (1986) Importance of ice edge phytoplankton production in the Southern Ocean. BioScience 36:251-257

Smith RC, Prézelin BB, Baker KS, Bidigare RR, and 9 others (1992) Ozone depletion: ultraviolet radiation and phytoplankton biology in Antarctic waters. Science 255: 952-959

Sommaruga R, Buma (2000) UV-induced cell damage is species-specific among phagotrophic protists. J Eukaryot Microbiol 47:450-455

Sommaruga R, Oberleiter A, Psenner R (1996) Effect of UV radiation on bactivory of a heterotrophic nanoflagellate. Appl Environ Microbiol 62:4395-4400

Sommaruga R, Sattler B, Oberleiter A, Wille A and 7 others (1999) An in situ enclosure experiment to test the solar UVB impact on plankton in a high altitude mountain lake: 
II. Effects on the microbial food web. J Plankton Res 21: 859-876

Suttle CA, Chen F (1992) Mechanisms and rates of decay of marine viruses in seawater. Appl Environ Microbiol 58: 3721-3729

Taalas P, Kaurola J, Kylling A, Shindell D and 6 others (2000) The impact of greenhouse gases and halogenated species on future solar UV radiation doses. Geophys Res Lett 27: $1127-1130$

Thomsen HA, Ikavalko J (1997) Species of Thaumatomastix (Thaumatomastigidae, Protista incettae sedis) from the Arctic sea ice biota (northwest water polynya) NE Greenland. J Mar Syst 10:263-277

Vernet M (2000) Effects of UV radiation of the physiology and ecology of marine phytoplankton. In: de Mora S, Demers $\mathrm{S}$, Vernet M (eds) The effects of UV radiation in the marine environment. Cambridge environmental chemistry series, Vol 10. Cambridge University Press, Cambridge, p 237-278

Veth C (1991) The evolution of the upper water layer in the marginal ice zone, Austral sporing 1988, Scotia-Weddell Sea. J Mar Syst 2:451-464

Villafañe VE, Helbling EW, Holm-Hansen O, Chalker BE

Editorial responsibility: David Karl,

Honolulu, Hawaii, USA
(1995) Acclimatization of Antarctic natural phytoplankton assemblages when exposed to solar ultraviolet radiation. J Plankton Res 17:2295-2306

Vincent WF, Roy S (1993) Solar ultraviolet-B radiation and aquatic primary production: damage protection and recovery. Environ Rev 1:1-12

Vørs N (1992) Ultrastructure and autecology of the marine heterotrophic flagellate Leucocryptos marina (Braud) Butcher 1967 (Katablepharidaceae/Kathablepharidae) with a discussion of the genera Leucocryptos and Katablepharis/Kathablepharis. Eur J Protistol 28:369-389

Voytek MA (1989) Ominous future under the ozone hole: assessing biological impacts in Antarctica. Environmental Defence Fund, Washington, DC, p 1-69

Wängberg SA, Selmer JS, Gustavson K (1996) Effects of UV-B radiation on biomass and composition in marine phytoplankton communities. Sci Mar 60:81-88

Wickham S, Carstens M (1998) Effects of ultraviolet-B radiation on two Arctic microbial food webs. Aquat Microb Ecol 16:163-171

Xiangdong Z, Honghua L, Xiuji Z (1999) A study on the 6 yr observation of the spring ozone depletion at Zhongshan Station, Antarctica. Chin J Polar Res 11:265-274

Submitted: December 6, 2000; Accepted: November 8, 2001 Proofs received from author(s): February 15, 2002 